\title{
The effectiveness of cinnamon powder and cinnamon leaf extract to prevent Aeromonas hydrophila infection on striped catfish Pangasianodon hypophthalamus
}

\section{Efektivitas tepung dan ekstrak daun kayu manis sebagai pencegah infeksi Aeromonas hydrophila pada ikan patin Pangasianodon hypophthalmus}

\author{
Erni Susanti ${ }^{1}$, Dinamella Wahjuningrum ${ }^{2 *}$, Sri Nuryati ${ }^{2}$, Mia Setiawati ${ }^{2}$ \\ ${ }^{1}$ Aquaculture Science, IPB Graduate School, IPB University \\ ${ }^{2}$ Department of Aquaculture, Faculty of Fisheries and Marine Sciences, IPB University \\ Dramaga, Bogor 16680, West Java, Indonesia \\ *Corresponding author: dinamellawa@apps.ipb.ac.id
}

(Received August 24, 2016; Accepted September 21, 2016)

\begin{abstract}
Striped catfish Pangasianodon hypophthalamus is one of the intensive cultured commodities. Disease outbreak becomes inevitable to prevent in a fish culture. One of the most frequent disease occurred in striped catfish is the motile aeromonas septicemia (MAS) disease caused by Aeromonas hydrophila. This study aimed to evaluate the effectiveness of $1 \%$ dietary cinnamon powder and $0.5 \%$ dietary cinnamon leaf extract on the immune response of striped catfish challenged with A. hydrophila. Striped catfish used in this study sizing of $5.80 \pm 0.21 \mathrm{~g}$. This study contained two phases, namely in vitro and in vivo tests. In vitro test contained inhibition zone and antibacterial tests, which demonstrates that $1 \%$ cinnamon powder and $0.5 \%$ cinnamon leaf extract are effective to inhibit $A$. hydrophila activity. In vivo test contained four treatments, i.e fish fed with $1 \%$ cinnamon leaf powder supplemented diet; $0.5 \%$ cinnamon leaf extract supplemented diet, positive control diet, and negative control diet. Each treatment was performed in three replications. The result showed that $1 \%$ cinnamon leaf powder supplemented diet obtained the best results to enhance the immune response of striped catfish higher survival rate value at $83.33 \%$ than the positive control diet $(\mathrm{P}<0.05)$.
\end{abstract}

Keywords: Aeromonas hydrophila, Cinnamomum burmannii, extract, Pangasianodon hypophthalmus, powder.

\begin{abstract}
ABSTRAK
Ikan patin Pangasianodon hypophthalamus termasuk komoditas yang banyak dibudidayakan secara intensif. Kendala budidaya seperti penyakit pun sulit untuk dihindari. Salah satu jenis penyakit yang kerap menyerang ikan patin yaitu penyakit MAS (motile aermomonad septicaemia) yang disebabkan oleh Aeromonas hydrophila. Penelitian ini bertujuan untuk menguji efektivitas $1 \%(\mathrm{w} / \mathrm{w})$ tepung dan $0,5 \%(\mathrm{w} / \mathrm{w})$ ekstrak daun kayu manis dalam pakan sebagai upaya pencegahan infeksi bakteri A. hydrophila pada ikan patin. Ikan patin yang digunakan berukuran 5,80 $\pm 0,21 \mathrm{~g}$. Penelitian ini terdiri dua tahap yaitu uji in vitro dan uji in vivo. Hasil uji in vitro terhadap aktivitas antibakteri menunjukkan bahwa dosis $1 \%(\mathrm{w} / \mathrm{w})$ tepung daun kayu manis dan $0.5 \%(\mathrm{w} / \mathrm{w})$ ekstrak daun kayu manis efektif dalam menghambat pertumbuhan A. hydrophila. Uji in vivo terdiri atas empat perlakuan yaitu pemberian pakan dengan penambahan tepung daun kayu manis $1 \%(\mathrm{w} / \mathrm{w})$, pemberian pakan dengan penambahan ekstrak daun kayu manis $0,5 \%(\mathrm{w} / \mathrm{w})$, kontrol positif, dan kontrol negatif dengan masing-masing perlakuan terdiri atas tiga ulangan. Hasil penelitian menunjukkan bahwa penambahan $1 \%(\mathrm{w} / \mathrm{w})$ tepung daun kayu manis dalam pakan memberikan hasil terbaik dalam meningkatkan respons imun ikan patin dengan tingkat kelangsungan hidup sebesar $83,33 \%$ lebih tinggi dibandingkan kontrol positif $(\mathrm{P}<0,05)$.
\end{abstract}

Kata kunci: Aeromonas hydrophila, Cinnamomum burmannii, ekstrak, Pangasianodon hypophthalmus, tepung 


\section{INTRODUCTION}

Striped catfish Pangasianodon hypophthalmus are freshwater fish species that are abundantly developed in intensive culture system due to high consumer demand. Based on the Directorate General of Aquaculture (DJPB, 2013), the striped catfish production in 2012 reached 347,000 ton and increased to 410,684 ton in 2013. However, intensive culture system will greatly increase fish outbreak incident in striped catfish. Disease caused by bacteria becomes one of the striped catfish culture problems that results in fish dead. The most frequent bacteria that attack striped catfish are Aeromonas hydrophila bacteria which cause MAS (motile aeromonas septicaemia) disease (Crumlish et al., 2010).

Preventive efforts to disease as effective ways in maintaining disease incidents are much easier than recovery efforts when fish are exposed to the disease. Disease maintenance effort often applies antibiotics such as oxytetracycline, which is still a part of disease recovery efforts. Moreover, the application of antibiotics has been limited due to bio-accumulative properties that can cause bacterial resistance on antibiotics (Pridgeon et al., 2011). Vaccination also has a potential for fish disease prevention, but vaccine application is inefficient as only specifically effective to MAS and relatively have an expensive price (Christybapita et al., 2007).

A possible potential that can be applied as MAS disease prevention effort is the use of phytopharmaceutical materials. Phytopharmaceutical materials are natural materials that can become a drug based on the clinical proof (Indriani et al., 2014). The application of phytopharmaceutical is an effective solution as a preventive way to disease due to environmentally friendly and safe for consumer without causing a negative impact when being consumed by fish. One of phytopharmaceutical materials that can be applied to prevent MAS disease is cinnamon plant (Cinnamomum burmannii). According to Gruenwald et al. (2010), cinnamon is a herbal plant with polyphenol and cinnamaldehyde contents as antioxidant properties. Jayaprakasha and Rao (2011) stated that the cinnamon essential oil contained bioactive compounds such as cinnamaldehyde that could increase lipid metabolism and play a role as an antioxidant.

Several studies have been performed by utilizing cinnamon, namely Rattanachaikunsopon and Phumkhachorn (2010) who utilized cinnamon essential oil and bark to inhibit Streptococcus iniae proliferation. The essential oil and bark of cinnamon from Cinnamomum verum contained cinnamaldehyde, lymonene, cinnamal-acetate, lynalool, and $\alpha$-terpineol; as $20 \mu \mathrm{g} / \mathrm{ml}$ concentration of each material could inhibit Streptococcus iniae proliferation (Rattanachaikunsopon \& Phumkhachorn, 2010). Safratilofa et al. (2015) reported that the dietary supplementation of $0.5 \%$ cinnamon leaf extract could improve non-specific immune repsonse of striped catfish on post-challenge test against $A$. hydrophila. Ahmad et al. (2011) presented that the dietary supplementation of $1 \%$ cinnamon (C. zeylanicum) powder had antibacterial characteristics against A. hydrophila infection in Nile tilapia. Further experiment on cinnamon leaf powder and extract needs to be performed to measure the effectiveness of both materials to improve the striped catfish immune system.

\section{MATERIALS AND METHODS}

\section{Cinnamon leaf powder preparation}

Cinnamon leaves from $C$. burmannii species were obtained from farmers in Jambi, Indonesia, and the leaves were picked, cleaned, and dried in an oven at $40^{\circ} \mathrm{C}$. After drying process, the dried leaves were grinded using a grinder machine and sieved until producing a smooth leaf powder for phytochemical test.

The cinnamon leaf extract was produced by extracting cinnamon leaves with $96 \%$ ethanol solvent. The extraction procedure was performed based on the modified method from Prasad et al. (2009). The cinnamon leaf simplicia was extracted at 1:10 (w/v) ratio between the sample and solvent. Extraction was performed through maceration method for 18 hours while being shaken using an orbital shaker. The filtrate was filtrated and evaporated using a rotary evaporator at $40^{\circ} \mathrm{C}$. The product was formed as a thick extract of cinnamon leaf for further phytochemical test. The phytochemical test results on the bioactive compounds of cinnamon leaf extract and powder are presented in Table 1.

\section{In vitro test}

The in vitro test contained bacterial preparation, inhibition zone test, and mixed culture. Available bacteria used for the test were A. hydrophila. A. hydrophila bacteria were initially characterized using the kit API 20E. These bacteria were then 
grown on TSA (trypticase soy agar) medium.

One ose of bacterial colony was taken and grown on the TSB (trypticase soy broth), then incubated in a waterbath shaker at $29^{\circ} \mathrm{C}$ on $140 \mathrm{rpm}$ speed for 24 hours. The identified $A$. hydrophila bacteria were used further for in vitro test with cinnamon leaf powder and extract.

The cinnamon leaf powder used in the antibacteria test was modified following the macrodilution method (NCLLS 2005) at $0.1 \%$ (w/w); $0.5 \%$ (w/w); $1 \%$ (w/w); $1.5 \%$ (w/w) doses with each dose had two replications. Cinnamon leaf extract was used for inhibition zone test following the Kirby-Bauer method (Satirapathkul \& Leela, 2011) at $0.1 \%(\mathrm{w} / \mathrm{w}) ; 0.5 \%(\mathrm{w} / \mathrm{w}) ; 1 \%$ $(w / w) ; 1.5 \%(w / w)$ doses with each dose had two replications. The antibacteria test result on cinnamon leaf powder was observed from the total colony grown as the less total colony observed, the stronger antibacterial characteristics occurred, while the inhibition zone test results on cinnamon leaf extract was observed from the clear zone area as the wider clear area around the paper disk, the greater antibacterial capacity occurred.

\section{In vivo test}

The fish used striped catfish $P$. hypophthalmus with an average weight of $5.80 \pm 0.21 \mathrm{~g}$. Fish were acclimatized in 12 aquaria at $60 \times 30 \times 30 \mathrm{~cm}^{3}$ size and $20 \mathrm{~cm}$ water height with 10 fish per aquarium.

The experimental design used in this study was a completely randomized design containing four treatments and three replications. The treatments applied were based on the previous study by Safratilofa (2015), namely fish were fed with $1 \%$ cinnamon leaf powder supplemented diet (w/w) and injected with A. hydrophila bacteria, fish were fed with $0.5 \%$ cinnamon leaf

Table 1. Phytochemical compounds of cinnamon leaf extract and powder

\begin{tabular}{lcccc}
\hline $\begin{array}{c}\text { Phytochemical } \\
\text { compound }\end{array}$ & $\begin{array}{c}\text { Cinnamon leaf } \\
\text { extract }(\%)\end{array}$ & $\begin{array}{c}0.5 \% \text { cinnamon } \\
\text { leaf extract }\end{array}$ & $\begin{array}{c}\text { Cinnamon leaf } \\
\text { powder }(\%)\end{array}$ & $\begin{array}{c}\text { 1\% cinnamon } \\
\text { leaf powder }\end{array}$ \\
\hline Flavonoids & 5.05 & 0.02525 & 1.80 & 0.018 \\
Tannins & 1.30 & 0.0065 & 2.74 & 0.0274 \\
Saponins & 3.65 & 0.01825 & 2.32 & 0.0232 \\
Cinnamaldehyde & 1.62 & 0.0081 & 59.46 & 0.5946 \\
\hline
\end{tabular}

Table 2. Diet formulation and proximate contents

\begin{tabular}{|c|c|c|c|}
\hline \multirow{2}{*}{ Ingredient } & \multicolumn{3}{|c|}{ Treatment diet } \\
\hline & PK & PT & $\mathrm{PE}$ \\
\hline Fish meal & 13 & 13 & 13 \\
\hline Soybean meal & 20 & 20 & 20 \\
\hline Bran pollard & 56 & 56 & 55.5 \\
\hline Cinnamon leaf powder & 0 & 1 & 0 \\
\hline Cinnamon leaf extract & 0 & 0 & 0.5 \\
\hline Tapioca flour & 3 & 3 & 3 \\
\hline Vitamin-mineral mix & 5 & 5 & 5 \\
\hline Total $(\%)$ & 100 & 100 & 100 \\
\hline \multicolumn{4}{|l|}{ Proximate content } \\
\hline Protein $(\%)$ & 32.08 & 31.91 & 32.00 \\
\hline Lipid (\%) & 9.34 & 7.97 & 8.73 \\
\hline Crude fiber (\%) & 7.22 & 8.95 & 7.59 \\
\hline Ash (\%) & 9.61 & 8.79 & 9.56 \\
\hline NFE $(\%)$ & 41.76 & 42.38 & 42.12 \\
\hline $\mathrm{GE}(\mathrm{kcal} / \mathrm{g})^{1}$ & 438.62 & 427.37 & 433.96 \\
\hline C/P Ratio (kcal/g protein $)^{2}$ & 13.67 & 13.39 & 13.56 \\
\hline
\end{tabular}

Note: 1) $1 \mathrm{~g}$ protein $=5.6 \mathrm{kcal}, 1 \mathrm{~g}$ carbohydrate $=4.1 \mathrm{kcal}, 1 \mathrm{~g}$ lipid $=9.4 \mathrm{kcal}$ (Watanabe, 1988), NFE $=$ nitrogen free extract. 2) energy/protein ratio. $\mathrm{PK}=$ diet without any cinnamon leaf products (control), $\mathrm{PT}=$ diet $+1 \%$ cinnamon leaf powder, $\mathrm{PE}=$ die $+0.5 \%$ cinnamon leaf extract. 
extract supplemented diet (w/w) and injected with A. hydrophila bacteria, positive control (fish were fed without any experiment materials, but being injected with $A$. hydrophila), and negative control (fish were fed fish were fed without any experiment materials, but being injected with phosphate buffer saline/PBS).

Diets were produced by preparing the diet ingredients, namely fish meal, soybean meal, bran pollard, cinnamon leaf powder, cinnamon leaf extract, tapioca flour, and vitamin-mineral mix, which were reshaped as pellet, before drying in an oven at $30^{\circ} \mathrm{C}$ for 24 hours. Diets produced were identified their nutrient contents through proximate analysis. Diet formulation and proximate analysis result of cinnamon leaf powder and extract supplemented diets in dry weight basis are presented in Table 2.

Fish were fed three times a day at 08.00, 12.00, and 17.00 GMT+7. Fish were maintained for 14 days. Fish in all treatments, except the negative control treatment, were injected with $10^{7} \mathrm{CFU} / \mathrm{ml}$ A. hydrophila at $0.1 \mathrm{~mL} /$ fish after 14 days of maintenance period. After injection, observation was performed for 13 days. Water quality condition was preserved by exchanging the water through syphonized method at 50\% once in two to three days. During maintenance period, the water quality condition was remained at temperature of $28-32^{\circ} \mathrm{C}$, $\mathrm{pH}$ of $7.50-8.00, \mathrm{DO}$ of $6.13-7.93 \mathrm{mg} / \mathrm{L}$, and TAN of $0.03-0.94 \mathrm{mg} / \mathrm{L}$. Treatment scheme design in in vivo test on striped catfish can be shown in Figure 1.

\section{Parameters}

Parameters observed in this study contained survival rate, water quality, and fish hematological profiles, such as hemoglobin level based on Sahli method (Wedemeyer \& Yasutake, 1977), hematocrit level based on Anderson and Siwicki (1993) method, total erythrocytes and total leukocytes levels based on Blaxhall and Daisley (1973) method, and respiratory burst based on Christybapita et al. (2007) method. The hematological profiles were observed on 2 days before injection (D-2), then 2, 6, and 13 days after injection $(\mathrm{D}+2, \mathrm{D}+6, \mathrm{D}+13)$.

\section{Data analysis}

The experimental design in this study used a completely randomized design method. Data were analyzed using SPSS 16.0. If there was a significant different occurred, the ANOVA analysis was used at $95 \%$ confidence level. Quantitative parameters analyzed in statistical way contained survival rate, hematological profiles, inhibition zone in in vitro test, and respiratory burst. Meanwhile, water quality parameters were analyzed descriptively.

\section{RESULTS AND DISCUSSIONS}

\section{Results}

The in vitro test results on cinnamon leaf extract showed a significant different value among treatments $(\mathrm{P}<0.05)$. The highest inhibition zone was obtained from $0.5 \%$ dose at $0.35 \mathrm{~cm}$ diameter

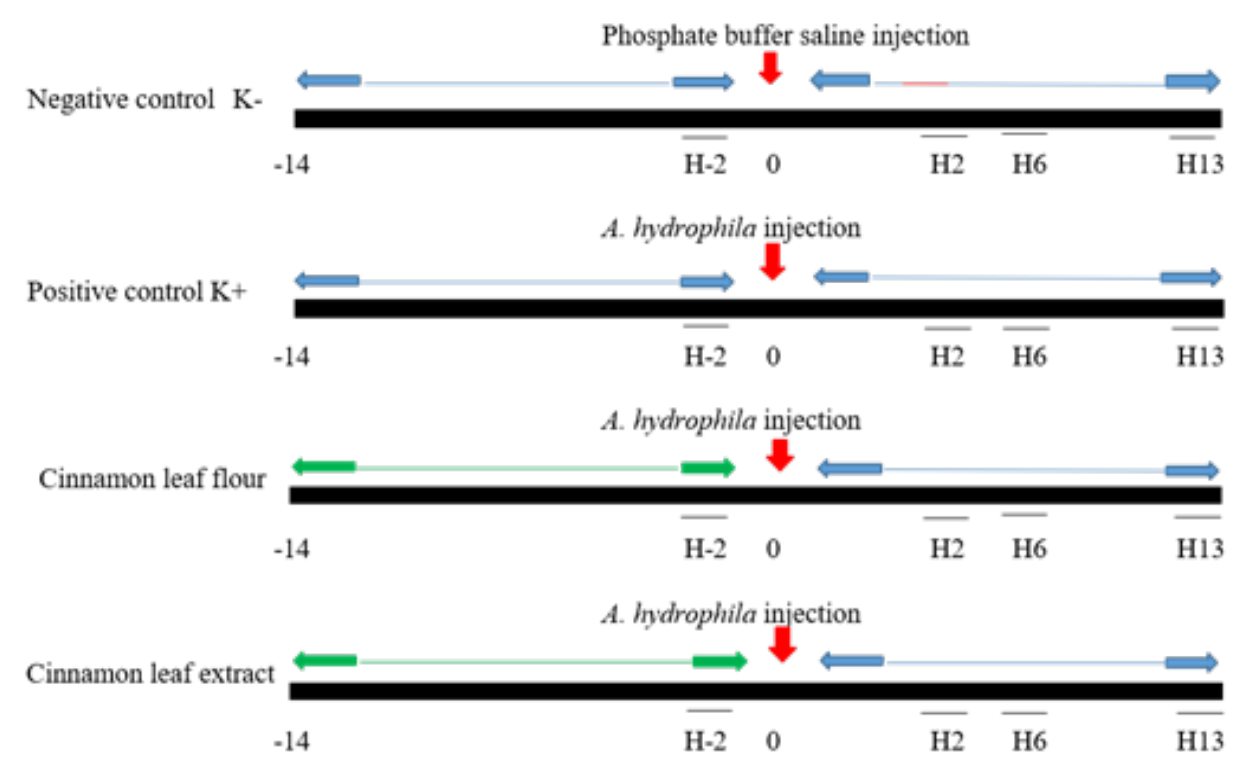

Figure 1. In vivo test scheme on fish: diets without cinnamon leaf product $\leftrightarrow$; diets with cinnamon leaf product $\leftrightarrow$ (D-2 before challenge test and D+2, D+6, D+13 after challenge test) 
Table 3. Inhibition zone diameter (cm) based on in vitro test against $A$. hydrophila bacteria using different cinn mon leaf extract doses

\begin{tabular}{ccccc}
\hline Code & \begin{tabular}{c} 
Cinnamon \\
leaf extract \\
\cline { 3 - 4 }
\end{tabular} & \multicolumn{2}{c}{ Replications } & Average \\
\cline { 3 - 4 } & dose & $1(\mathrm{~cm})$ & $2(\mathrm{~cm})$ & \\
\hline A & $0.1 \%$ & 0.20 & 0.20 & $0.2^{\mathrm{b}}$ \\
$\mathrm{B}$ & $0.5 \%$ & 0.40 & 0.30 & $0.35^{\mathrm{a}}$ \\
$\mathrm{C}$ & $1 \%$ & 0.30 & 0.20 & $0.25^{\mathrm{ab}}$ \\
$\mathrm{D}$ & $1.50 \%$ & 0.20 & 0.20 & $0.2^{\mathrm{b}}$ \\
\hline
\end{tabular}

*Different superscript letters in the same column show a significant different value $(\mathrm{P}<0.05)$. A: Treatment with $0.1 \%$ dose; B: Treatment with $0.5 \%$ dose; $\mathrm{C}$ : Treatment with $1 \%$ dose; D: Treatment with $1.5 \%$ dose

(Table 3). The inhibition zone dimension result using cinnamon leaf extract at $0.5 \%$ dose could inhibit bacterial growth due to producing full and great inhibition zone with an average size of 0.35 $\mathrm{cm}$. This result followed Sakinah (2014) who stated that $0.5 \%$ dose could obtain the greatest inhibition zone at $0.35-0.37 \mathrm{~cm}$. Furthermore,
Salikin (2014) also mentioned a similar statement as powder product from leaf extract (phytopharmaceutical) was a good material to produce inhibition zone of bacterial growth that attacked fish.

The in vitro results on cinnamon leaf powder which obtained a growth inhibition of $A$. hydrophila was found on $1 \%$ dose. This dose was used due to producing the least bacterial growth (Table 4). The in vitro test results on cinnamon leaf powder against $A$. hydrophila bacteria at $1 \%$ dose showed the least colony at $1.261 .26 \times$ $10^{10} \mathrm{CFU} / \mathrm{mL}$. This condition followed Marlinda (2014) who stated that the natural product which obtained the least bacterial colony was cinnamon leaf powder. This statement was also stated by Talpur et al. (2015) that the best dose to reduce total bacterial colony was $1 \%$.

Fish survival rate in final observation period can be presented in Figure 2. The highest survival rate was obtained from negative control at $90.00 \pm 10.00 \%$. In cinnamon leaf powder supplementation treatment, the survival rate

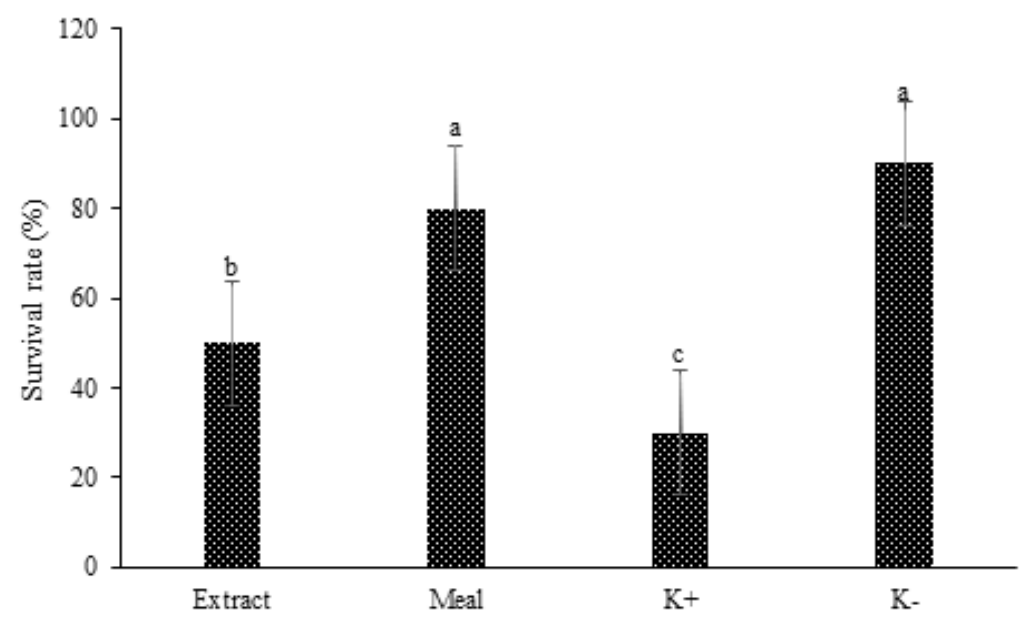

Figure 2. Survival rate of striped catfish after challenge test fed with cinnamon leaf extract supplemented diet, cinnamon leaf powder supplemented diet, commercial diet without cinnamon leaf product and with artifical infection $(\mathrm{k}+)$, and commercial diet without cinnamon leaf product and artificial infection (k-). Different letters show a significant different value $(\mathrm{P}<0.05)$.

Table 4. In vitro test on A. hydrophila bacteria using different cinnamon leaf powder doses

\begin{tabular}{ccccc}
\hline \multirow{2}{*}{ Code } & \multirow{2}{*}{ Cinnamon leaf powder dose } & \multicolumn{2}{c}{ Replication } & \multirow{2}{*}{$\begin{array}{c}\text { Total bacterial colony } \\
\text { (CFU/mL) }\end{array}$} \\
\cline { 3 - 4 } & & 1 (colony) & 2 (colony) & \\
\hline $\mathrm{A}$ & $0.1 \%$ & 187 & 200 & $7.74 \times 10^{10}$ \\
$\mathrm{~B}$ & $0.5 \%$ & 150 & 120 & $5.40 \times 10^{10}$ \\
$\mathrm{C}$ & $1 \%$ & 23 & 40 & $1.26 \times 10^{10}$ \\
$\mathrm{D}$ & $1.5 \%$ & 350 & 200 & $1.10 \times 10^{11}$ \\
\hline
\end{tabular}

Note: A: Treatment with $0.1 \%$ dose; B: Treatment with $0.5 \%$ dose; C: Treatment with $1 \%$ dose; D: Treatment with $1.5 \%$ dose 
value reached $83.33 \pm 5.77 \%$. Meanwhile, cinnamon leaf extract supplementation treatment obtained a survival rate value at $53.33 \pm 5.77 \%$ and the lowest survival rate value was obtained from positive control at $26.67 \pm 5.77 \%$. Based on the statistical analysis on survival rate value, negative control and cinnamon leaf powder supplementation treatments were insignificantly different $(\mathrm{P}>0.05)$, while positive control and cinnamon leaf extract supplementation treatments were significantly different $(\mathrm{P}<0.05)$ as both treatments also obtained a significant different compared to other treatments. The survival rate value of striped catfish is presented in Figure 2.

The calculation result of hematocrit level is presented Figure 3. On 2 days before challenge test (D-2), the hematocrit level in all treatments was insignificantly different $(P>0.05)$, except in negative control treatment $(\mathrm{P}<0.05)$. On $\mathrm{D}+2$, $\mathrm{D}+6$, and $\mathrm{D}+13$, the hematocrit level in all treatments were significantly different $(\mathrm{P}<0.05)$. The hematocrit level in cinnamon leaf powder supplemented diet treatment was significantly higher than other treatments on 2 days after challenge test $(\mathrm{D}+2)$.

The calculation result of fish hemoglobin level is presented in Figure 4. On 2 days before challenge test (D-2), the hemoglobin level in all treatments were insignificantly different $(\mathrm{P}>0.05)$, except in negative control $(\mathrm{P}<0.05)$. In $\mathrm{D}+2$, the hemoglobin level in cinnamon leaf powder and negative control treatments were insignificantly

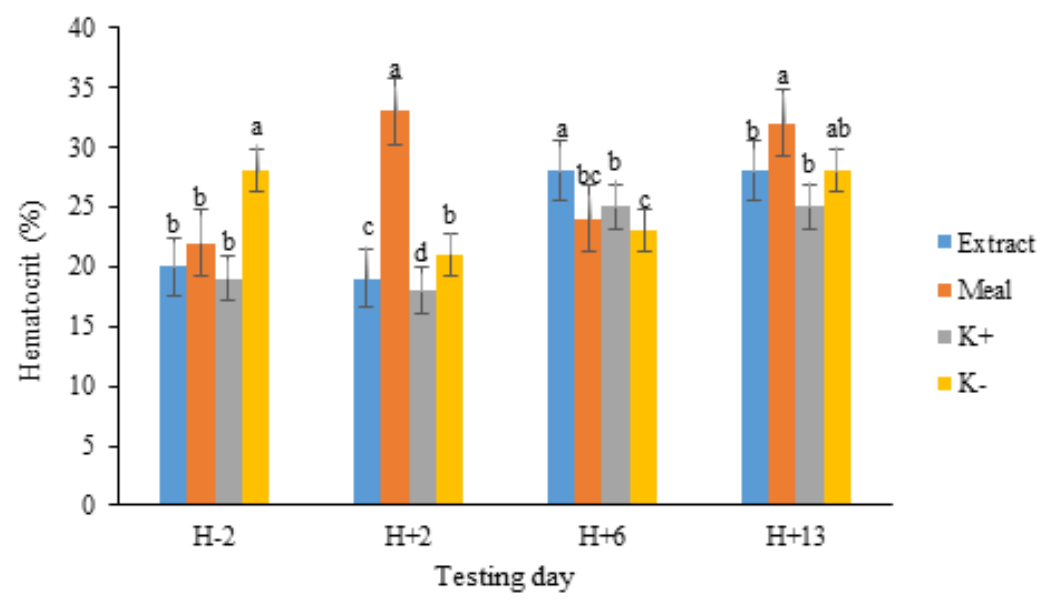

Figure 3. Hematocrit level of striped catfish fed with cinnamon leaf extract supplemented diet and injected with A. hydrophila, cinnamon leaf powder supplemented diet and injected with A. hydrophila, commercial diet without cinnamon leaf product supplementation and with artificial injection $(\mathrm{k}+)$, commercial diet without cinnamon leaf product supplementation and artificial injection (k-) on D-2 (before challenge test), D+2, D+6, D+13 (after challenge test). Note: Different letters on the same day show a significant different value $(\mathrm{P}<0.05)$.

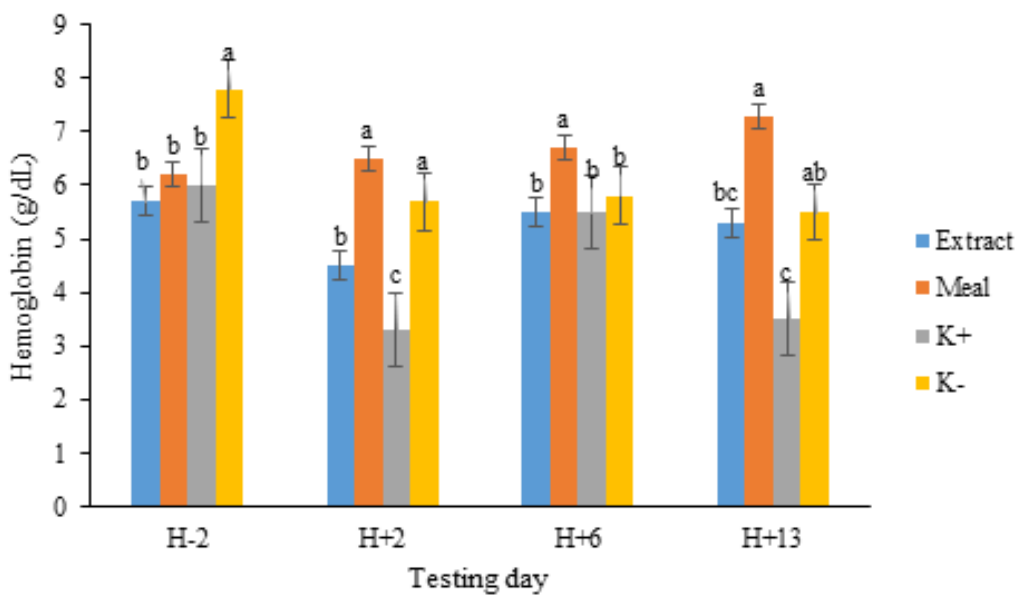

Figure 4. Hemoglobin level of striped catfish fed with cinnamon leaf extract supplemented diet and injected with A. hydrophila, cinnamon leaf powder supplemented diet and injected with A. hydrophila, commercial diet without cinnamon leaf product supplementation and with artificial injection $(\mathrm{k}+)$, commercial diet without cinnamon leaf product supplementation and artificial injection (k-) on D-2 (before challenge test), D+2, D+6, D+13 (after challenge test). Note: Different letters on the same day show a significant different value $(\mathrm{P}<0.05)$. 
different $(\mathrm{P}>0.05)$, but both treatments were significantly different from other treatments $(\mathrm{P}<0.05)$, while hemoglobin level in cinnamon leaf extract and positive control treatments were significantly different $(\mathrm{P}<0.05)$ and both treatments also obtained a significant difference between other treatments. On D+6, cinnamon leaf powder treatment was significantly different from other treatments $(\mathrm{P}<0.05)$, but cinnamon leaf extract, positive control, and negative control treatments were insignificantly different $(\mathrm{P}>0.05)$. On $\mathrm{D}+13$, the hemoglobin level in all treatments were significantly different $(\mathrm{P}<0.05)$. The hemoglobin level on D+2, D+6, and D+13 in cinnamon leaf powder treatment was significantly higher than other treatments.

The calculation result of total leukocyte is presented in Figure 5. Total leucocyte on D-2 before challenge test in cinnamon leaf powder and negative control treatments obtained an insignificant difference, but both treatments obtained a significant difference between other treatments, while cinnamon leaf extract and positive control treatments were significantly different $(\mathrm{P}<0.05)$ as both treatments were also significantly different from other treatments. On $\mathrm{D}+2$, cinnamon leaf powder and extract treatments were insignificantly different $(P>0.05)$, but both treatments obtained a significant different between other treatments $(\mathrm{P}<0.05)$, while positive

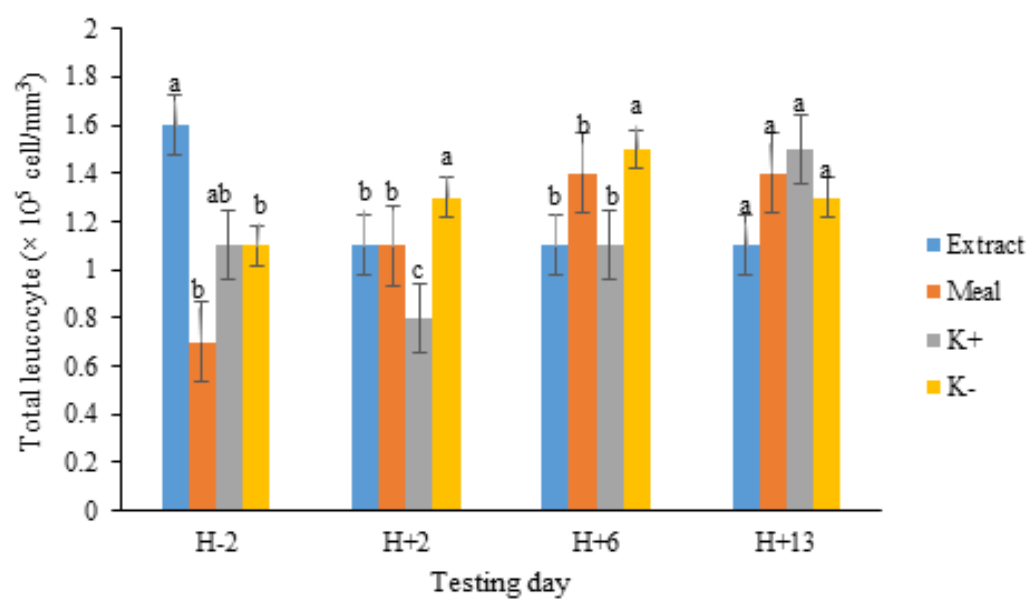

Figure 5. Total leukocyte of striped catfish fed with cinnamon leaf extract supplemented diet and injected with $A$. hydrophila, cinnamon leaf powder supplemented diet and injected with A. hydrophila, commercial diet without cinnamon leaf product supplementation and with artificial injection $(\mathrm{k}+)$, commercial diet without cinnamon leaf product supplementation and artificial injection (k-) on D-2 (before challenge test), D+2, D+6, D+13 (after challenge test). Note: Different letters on the same day show a significant different value $(\mathrm{P}<0.05)$.

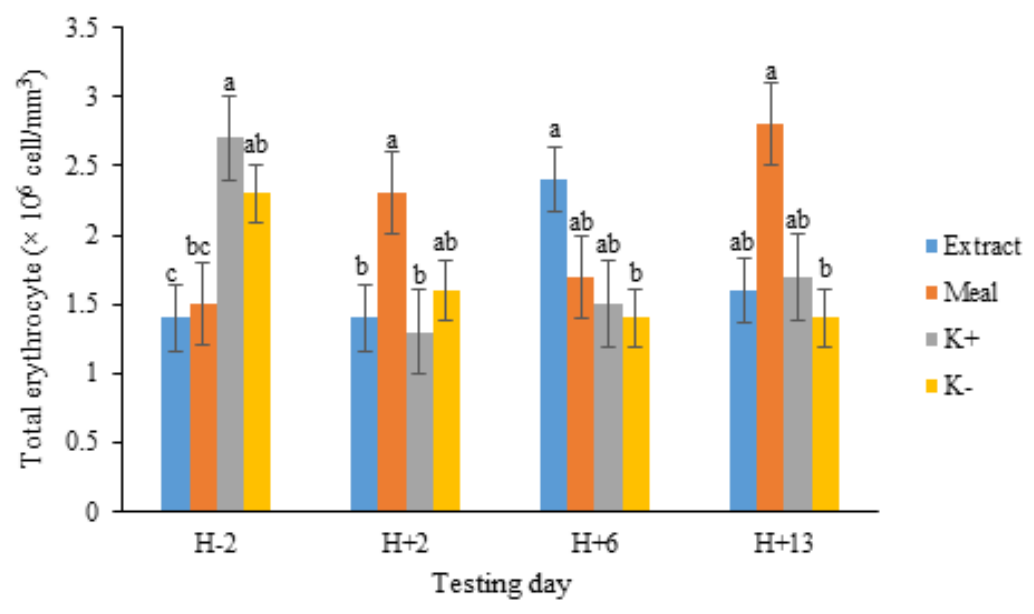

Figure 6. Total erythrocyte of striped catfish fed with cinnamon leaf extract supplemented diet and injected with A. hydrophila, cinnamon leaf powder supplemented diet and injected with $A$. hydrophila, commercial diet without cinnamon leaf product supplementation and with artificial injection $(\mathrm{k}+)$, commercial diet without cinnamon leaf product supplementation and artificial injection (k-) on D-2 (before challenge test), D+2, D+6, D+13 (after challenge test). Note: Different letters on the same day show a significant different value $(\mathrm{P}<0.05)$. 
and negative control treatments were significantly different $(\mathrm{P}>0.05)$. On $\mathrm{D}+6$, either cinnamon leaf extract, cinnamon leaf powder, and positive control obtained an insignificant difference $(\mathrm{P}>0.05)$, while negative control obtained a significant difference among other treatments. On $\mathrm{D}+13$, all treatments were insignificantly different $(\mathrm{P}>0.05)$. Total leukocyte on cinnamon leaf powder was significantly higher than other treatments on 6 days after challange test $(D+6)$.

The calculation result of total erythrocyte is presented in Figure 6. On D-2 before challenge test, total erythrocyte in all treatments were significantly different $(\mathrm{P}<0.05)$. On $\mathrm{D}+2$, cinnamon leaf extract and positive control treatments were insignificantly different $(\mathrm{P}>0.05)$, but both treatments were significantly different from other treatments $(\mathrm{P}<0.05)$. Meanwhile, cinnamon leaf powder and negative control treatments were significantly different from other treatments $(\mathrm{P}<0.05)$. On $\mathrm{D}+6$, cinnamon leaf powder and positive control treatments were insignificantly different $(\mathrm{P}>0.05)$ from other treatments, but cinnamon leaf extract and negative control treatments were significantly different $(\mathrm{P}<0.05)$ and both treatments were also significant different from other treatments. On $\mathrm{D}+13$, cinnamon leaf extract and positive control treatments were insignificantly different $(\mathrm{P}>0.05)$, but both treatments were significantly different $(\mathrm{P}<0.05)$ from other treatments, while cinnamon leaf powder and negartive control treatments were significantly different $(\mathrm{P}<0.05)$.

The calculation result of respiratory burst activity (RB) value is presented in Figure 7. On
$\mathrm{D}-2$ before challenge test, the $\mathrm{RB}$ value in all treatments were insignificantly different $(\mathrm{P}>0.05)$. On $\mathrm{D}+2$, all treatments were significantly different. On D+6, cinnamon leaf extractand positive control treatments were insignificantly different $(\mathrm{P}>0.05)$, but both treatments were significantlty different from other treatments $(\mathrm{P}<0.05)$. Meanwhile, cinnamon leaf powder and negative control treatments were significantly different $(\mathrm{P}<0.05)$ from other treatments. On D+13, cinnamon leaf extract and powder treatments were significantly different $(\mathrm{P}<0.05)$, and both treatments were also significantly different from othe treatments, while positive and negative control treatments obtained an insignificantly different value $(\mathrm{P}>0.05)$.

\section{Discussions}

The in vitro test is a method used to testify the antibacterial activity of cinnamon leaf powder and extract in inhibiting A. hydrophila growth. Based on the inhibition zone test of cinnamon leaf extract against $A$. hydrophila bacteria, $0.5 \%$ cinnamon leaf extract dose obtained the greatest inhibition zone at $0.35 \mathrm{~cm}$ (Table 3). Meanwhile, the result of in vitro test on cinnamon leaf powder, $1 \%$ cinnamon leaf poweder was the best dose to inhibit bacterial growth (Table 4). This condition was related to phytochemical contents of cinnamon leaves, such as flavonoids, saponnins, tannins, alkaloids, and cinnamaldehyde (Table 2) as antibacterial properties. The antibacterial mechanism from flavonoids occurs by forming a complex bond between protein through the hydrogen bound, followed by hydrophobic effect by forming covalent bond, resulting in DNA

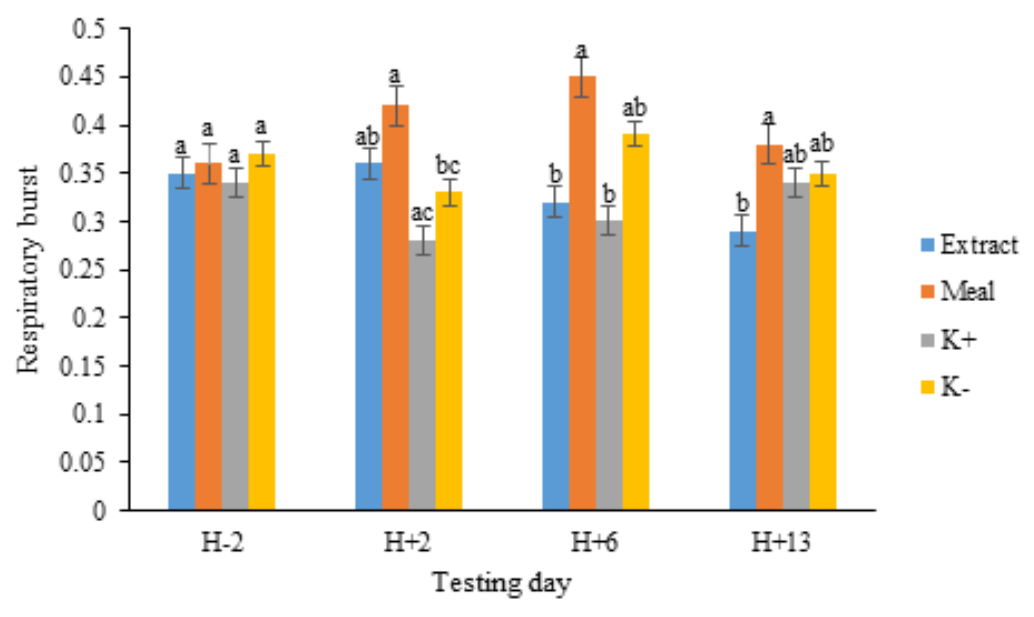

Figure 7. The respiratory burst activity of striped catfish fed with cinnamon leaf extract supplemented diet and injected with A. hydrophila, cinnamon leaf powder supplemented diet and injected with $A$. hydrophila, commercial diet without cinnamon leaf product supplementation and with artificial injection $(\mathrm{k}+)$, commercial diet without cinnamon leaf product supplementation and artificial injection (k-) on D-2 (before challenge test), D+2, D+6, $\mathrm{D}+13$ (after challenge test). Note: Different letters on the same day show a significant different value $(\mathrm{P}<0.05)$. 
synthesis inhibition and bacterial macromolecular synthesis inhibition (Agati et al., 2012). Saponnins inhibit bacterial growth by inhibiting bacterial protein synthesis that causes bacterial component formation change (Rosyidah et al., 2010). Alkaloids are antibacterial agent with the mechanism of disrupting bacterial ions and protein (Queiroz et al., 2013). Microbial inhibition mechanism on tannins hydrolysis occurs by causing bacterial enzyme inactivation (Makkar, 2003). Rattanachaikunsopon and Phumkhanchorn (2010) reported that $1.57 \%$ cinnamon (C. verum) essential oil containing $90.24 \%$ cinnamaldehyde could inhibit Streptococcus iniae growth. Moreover, Belguith et al. (2010) stated that the inhibition zone was formed due to bacterial sensitivity against the materials used.

Survival rate is a parameter used to testify the materials used to prevent $A$. hydrophila infection on striped catfish. The study result showed that the dietary supplementation of cinnamon leaf powder could significantly provide higher survival rate content than positive control treatment. In cinnamon leaf powder dietary supplementation treatment, the survival rate value reached at $83.33 \%$ which was insignificantly different from negative control treatment at $90.00 \pm 10.00 \%$. Meanwhile, the dietary supplementation of cinnamon leaf extract produced survival rate value at $53.33 \%$ and positive control treatment at $26.67 \%$. Increased survival rate in cinnamon leaf powder was thought due to striped catfish capability to improve their immune system and health. This condition occurred based on the bioactive compound content in $1 \%$ cinnamon leaf powder which showed a higher compound content level than cinnamon leaf extract (Table 1).

Based on phytochemical analysis of cinnamon leaf powder, $1 \%$ cinnamon leaf powder contained $0.018 \%$ flavonoids, $0.0274 \%$ tannins, $0.0232 \%$ saponins, and $0.5946 \%$ cinnamaldehyde. Meanwhile, $0.5 \%$ cinnamon leaf extract contained $0.02525 \%$ flavonoids, $0.0065 \%$ tannins, $0.01825 \%$ saponins, and $0.0081 \%$ cinnamaldehyde (Table 1). According to Ahmad et al. (2011), 1\% cinnamon leaf powder dietary supplementation could improve the immune system in Nile tilapia. Furthermore, Sivagurunathan and Innocent (2014) informed that $1 \%$ cinnamon powder could increase growth and health status of Nile tilapia.

Immune system in fish can be identified based on fish blood profile which represents fish health condition (Wedemeyer \& Yasutake, 1977). Blood profile parameters that can represent fish body condition change are hematocrit, hemoglobin, total erythrocyte, total leukocyte, and respiratory burst (RB). Hematocrit, hemoglobin, total erythrocyte, total leukocyte, and RB levels after challlenge test on cinnamon leaf powder treatment obtained a significant different value $(\mathrm{P}<0.05)$ among other treatments. This parameter increased as thought due to bioactive compounds of cinnamon leaf powder that were effective to improve the immune system of striped catfish. This increased level was similar to Ahmad et al. (2011) as 1\% cinnamon powder dietary supplementation could improve hematocrit, erythrocyte, and hemoglobin level of Nile tilapia on post-infection of A. hydrophila bacteria. According to Jayaprakasha and Rao (2011), the cinnamaldehyde content in cinnamon can be functioned as an antioxidant. Sabitha et al. (2014) added that antioxidant materials can improve body immune system form pathogenic bacteria attack and preserve the cell physiological condition to remain normal, besides reducing cell disruption due to free radicals and oxidative stress.

The observation result of total leukocyte in negative control and cinnamon leaf powder treatments were insignificantly different from cinnamon leaf extract treatment which increased after challenge test with A. hydrophila. This condition was similar to Safratilofa (2015) who stated that controlling treatment by supplementing $0.5 \%$ cinnamon leaf extract in the diet could improve total leukocyte, phagocytic activity, and respiratory burst activity of striped catfish. A. hydrophila bacteria causes fish to send leukocyte in excessive level to the infection site as part of body immune system. Leucocyte are functioned in body immune system and their total value increases extremely when the infection occurs (Talpur \& Ikhwanuddin, 2013). Yeh et al. (2009) stated that increased RB activity in white shrimp (Litopenaeus vannamei) fed with cinnamon occurred due to cinnamon bioactive compounds that could activate the immune system and increase the RB activity in shrimp infected with Vibrio alginolyticus. Previous study results reported that the supplementation of plant extracts either through injection or oral in different fish species obtained an increased RB value in fish (Yuan et al., 2007; Wu et al., 2010). A similar condition also occurred in this study as the dietary supplementation of cinnamon leaf powder and extract could increase the RB activity in striped catfish. 


\section{CONCLUSION}

The dietary supplementation of $1 \%$ cinnamon leaf powder could improve fish immune against A. hydrophila by obtaining a survival rate value of $83.33 \%$ in striped catfish.

\section{REFERENCES}

Ahmad MH, El Mesallamy AMD, Samir F, Zahran F. 2011. Effect of cinnamon Cinnamomum zeylanicum on growth performance, feed utilization, whole-body composition, and resistance to Aeromonas hydrophila in Nile tilapia. Journal of Applied Aquaculture 23: 289-298.

Agati G, Azzarello E, Pollastri S, Tattini M. 2012. Flavonoids as antioxidant in plant. Plant Science 196: 67-76.

Anderson DP dan Siwicki AK. 1993. Basic haematology and serology for fish health programs. Prosiding Second Symposium on Diseases in Asia Aquaculture "aquatic animal health and the environmental". Phuket Thailand

Belguith H, Kthiri F, Chati A, Sofah AA, Hamida JB, Ladoulsi A. 2010. Inhibition effect of aqueous garlic extract Allium sativum on some isolated Salmonella serovars. African Journal of Microbiology Research 4: 328-338.

Blaxhall PC, Daisley KW. 1973. Reutine haemotologycal methods for use with fish blood. Journal Fish Biology 5: 577-581.

Christybapita D, Divyagnaneswari M, Michael RD. 2007. Oral administration of Elipta alba leaf for enhance the non spesific immune response and disease resistence of Orechromis mossambicus. Fish and Shellfish Immunology 23: 840-852.

Crumlish M, Thanh PC, Koesling J, Tung VT, Gravningen K. 2010. Experimental challenge studies in Vietnamese catfish, Pangasianodon hypophthalmus (Sauvage), exposed to Edwardsiella ictaluri and Aeromonas hydrophila. Journal of Fish Diseases 33: 717722.

DJPB Direktorat Jenderal Perikanan Budidaya. 2013. Statistik menakar target air tawar tahun 2013. http://www.djpb.kkp.go.id/berita. php?id=847 [1 September 2014].

Gruenwald J, Freder J, Armbruster N. 2010. Cinnamon and Health. Critical Reviews in Food Science and Nutrition 50: 822-834.
Indriani AD, Slamet BP, Sarjito. 2014. Penggunaan jahe merah (Zingiber officinale var. Rubrum) sebagai alternative pengobatan ikan nila Oreochromis niloticus yang diinfeksi bakteri Aeromonas hydrophila. Journal of Aquaculture Management and Technology 3: 58-65.

Jayaprakasha GK, Rao LJM. 2011. Chemistry, Biogenesis, and Biological Activities of Cinnamomum zeylanicum. Critical Reviews in Food Science and Nutrition 51: 547-562

Makkar HPS. 2003. Effect and fate of tannins in ruminant animals, adaptation to tannins and strategies to overcome detrimental effects of feeding tannin-rich feeds. Small Ruminant Research 49: 241-256.

Marlinda S. 2014. Evaluation of growth and nutrient quality of catfish Pangasius sp. reared using kayu manis leaf Cinnamomum burmanni meal enriched diet. Bogor (ID). Institut Pertanian Bogor.

[NCLLS] National Committee of Clinical Clinical Laboratory Standards, 2005. Manual of antimicrobial susceptibility testing. American Society Microbiol 4: 39-52.

Prasad KN, Dong BYX, Jiang G, Zhang H, Xie H, Jiang Y. 2009. Flavonoid contents and antioxidant activities from Cinnamomum species. Innovative Food Science and Emerging Technologies 10: 627-632.

Pridgeon JW, Klesius PH, Song L, Zhang D, Kojima K, Mobley JA. 2011. Identification, virulence, and mass spectrometry of toxic ECP fractions of West Alabama isolates of Aeromonas hydrophila obtained from 2010 disease outbreak. Veterinary Microbiology 164: 336-343.

Queiroz MMF, Marti G, Queiroz EF. 2013. Quantitative determination of Tetrapterys mucuronata Alkaloids. Phytochem 1: 1-12.

Rattanachaikunsopon P, Phumkhachorn P. 2010. Potential of cinnamon Cinnamomum verum oil to control Streptococcus iniae infection in tilapia Oreochromis niloticus. Fisheries Science 76: 287-293.

Rosyidah K, Numuhaimina SA, Komari N, Astuti MD. 2010. Aktivitas antibakteri fraksi saponin dari kulit batang tumbuhan kasturi Magnifera casturi. ALCHEMY 1: 53-65.

Sabitha K, Venugopal B, Rafi MD, Ramana KV. 2014. Role of antioxidant enzymes in glucose and lipid metabolism in association with obesityand type 2 diabetes. American Journal of Medical Sciences and Medicine 2: 21-24. 
Safratilofa. 2015. Potensi ekstrak daun kayu manis Cinnamomun burmanii untuk meningkatkan respon imun ikan patin Pangasianodon hypophthalmus yang diinfeksi Aeromonas hydrophila. Institut Pertanian Bogor . Bogor (ID),

Safratilofa, Wahjuningrum D, Jusadi D, Setiawati M. 2015. Effect of cinnamon, Cinnamomun burmanii, leaves extract for non specific immune response in striped catfish Pangasianodon hypophthalmus (Sauvage, 1878) infected by Aeromonas hydrophila. Jurnal Iktiologi Indonesia 15: 223-233.

Salikin RQ, Sarjito, Prayitno SB. 2014. Pengaruh perendaman ekstrak daun binahong Anredera cordifolia terhadap mortalitas dan histologi hati ikan mas Cyprinus carpio yang diinfeksi bakteri Aeromonas caviae. Journal of Aquaculture Management and Technology 3: 43-50.

Sakinah A. 2014. Evaluasi pertumbuhan dan kualitas daging ikan patin Pangasius sp. Pada periode tertentu yang diberi pakan mengandung daun kayu manis Cinnamomum burmanni. Institut Pertanian Bogor. Bogor (ID).

Satirapathkul C, Leela T. 2011. Growth inhibiting of pathogenic bacteria by extract of quercus infectoria galls. Bioscience 1: 1-6.

Sivagurunathan A, Innocent BX. 2014. Immunomodulatory effect of dietary cinnamon in growth and haematology of tilapia challenged with Pseudomonas aeruginosa.
International Journal of Pharmaceutical and Phytopharmacological Research 3: 277-280.

Talpur AD, Ikhwanuddin M. 2013. Azadirachta indica neem leaf dietary effects on the immunity response and disease resistance of Asian seabass, Lates calcarifer challenged with Vibrio harveyi. Fish and Shellfish Immunology 34: 254-264.

Wedemeyer GA, Yasutake WT. 1977. Clinical Methods for the Assessment of the Effect Environment Stress on the Fish Health. Technical Papers of the US Fish and Wildlife Service. US: Depart of the Interior Fish and Wildlife Service 89: 1-17.

Wu CC, Liu CH, Chang YP, Hsieh SL. 2010. Effect of hot-water extract of Toona sinensis on immune response and resistance to Aeromonas hydrophila in Oreochromis mossambicus. Fish and Shellfish Immunology 29: 258-263.

Yeh RY, Shiu YL, Shei SC, Cheng SC, Huang SY, Lin JC, Liu CH. 2009. Evaluation of the antibacterial activity of leaf and twig extracts of stout camphor tree, Cinnamomum kanehirae, and the effects on immunity and disease resistance of white shrimp, Litopenaeus vannamei. Fish and Shellfish Immunology 27: 26-32.

Yuan C, Li D, Chen W, Sun F, Wu G, Gong Y, Tang J, Shen M, Han X. 2007. Administration of a herbal immune-regulation mixture enhances some immune parameters in carp Cyprinus carpio. Fish Physiology and Biochemistry 33: 93-101. 